\title{
Analysis of the System of Cornea Donation in the State of Paraná in the Period from 2011 To 2016
}

\author{
Martins Matias da DS1*, Quina MJ $^{2}$, Silva S $^{2}$, Trevisan $\mathrm{J}^{1}$ and \\ Fernandez Lourenço MC1 \\ ${ }^{1}$ Londrina State University, Brazil \\ 2Maringá State University, Brazil

\section{Research Article \\ Volume 3 Issue 1} \\ Received Date: December 14, 2018 \\ Published Date: January 03, 2019 \\ DOI: $10.23880 /$ nhij-16000169
}

*Corresponding author: Dayanna Saeko Martins Matias da Sulva, Universidade Estadual de Londrina, Rodovia Celso Garcia Cid - Pr 445 Km 380 Cx. Postal 10.011 - Campus Universitário, PR, 86057-970, Brazil, Tel: 55043 999514020; Email: dayannasaeko@outlook.com

\section{Abstract}

Objective: Analyze the cornea donation in the State of Paraná-Brazil.

Methods: This was an evaluative and cross-sectional study. The data sources were medical records of potential donors with death due to brain death and cardiorespiratory arrest that occurred in Paraná between January of 2011 and December of 2016 whose were analyzed in the Statistical Package for Social Sciences (SPSS) version 20.0. Absolute and relative frequencies and median and interquartile ranges were calculated in the descriptive statistical analysis. Odds ratios were used with a respective confidence interval of $95 \%$ to assess associations between variables. The Wald test was used to determine differences considering $\mathrm{p}<0.05$.

Results: Among 7,622 eligible donors identified in the analyzed period, 6,624 (86.9\%) were cornea donors, of which, 3,685 were effectively transplanted. The chances of effective cornea donations were higher among men who died from brain death occurring in the Eastern Macroregional of the state. A significant drop in the number of donations was observed over the years within the studied period.

Conclusions: The results of this study demonstrate that, although Paraná has shown a decline in corneal donations in the last five years, the state could overcome barriers and increase donation rates, reduce waiting times, and meet the patient awaiting the transplant with quality care as the result of awareness of the society, improvement in public policies, and professional qualification in the health area and in all involved in the process.

Keywords: Tissue and Organ Procurement; Cornea; Process Assessment (Health Care)

Abbreviations: EBAA: Eye Bank Association of America; OPO: Organ Procurement Organizations; SPSS: Statistical Package for Social Sciences. 


\section{Nursing \& Healthcare International Journal}

\section{Introduction}

Cornea transplantation is one of the world's most successful types of transplant because of the number of donations and technical easiness [1]. There are several disorders that affect the cornea such as keratoconus, bullous keratopathy, leukoma of any etiology, Fuchs dystrophy and other corneal dystrophies, interstitial keratitis, corneal degeneration, ocular burning, congenital corneal anomalies, primary, secondary, or late-onset collapse, ocular globe perforation or imminent corneal perforation, bilateral corneal opacity, and corneal ulcer unresponsive to clinical treatment $[2,3]$.

The enucleation of the ocular globe can be performed within 6 hours after cardiorespiratory arrest (CRP) and presents an ischemia time of up to 7 days, different from other organs, whose maximum time is 24 hours [4]. In addition, the cornea is a tissue without vascularization[5].

The corneal tissue is a transparent dome-shaped membrane that covers the frontal eye region and protects the pupil, iris, and the inner eye from foreign bodies; this tissue is the first and most powerful element of the vision system. In addition to being innervated, it is very sensitive to pain and touch $[5,6]$.

Corneal pathologies are the third cause of blindness in the world, which lead to decreased visual acuity that can cause both individually and collectively limiting damages [7]. These limitations often cause the individual to lose a job, experience income decrease and financial and/or physical dependence that can generate a loss of selfesteem and other issues. Collectively, economic and social data show point to these limitations because corneal diseases usually affect economically active youngsters [8].

Keratoconus is the corneal disease responsible for most transplants in Brazil and worldwide [9]. Keratoconus is understood as a cornea progressive protrusion and thinning, compromising the visual function [10]. Its prevalence varies according to geographical locations and diagnostic criteria. The prevalence is 50: 100,000 worldwide and mainly in Western populations [11]. In Brazil, there are prevalence variations according to regions and reference centers [9].

Corneal transplantation is the option for the sight recovery of individuals afflicted with severe corneal diseases; however, it is a factor directly proportional to the number of donations from deceased donors [2].
After the donor's death and family permission, the cornea uptake can be performed by a qualified professional even outside the hospital environment, and not necessarily by a doctor. The maintenance of corneas requires keeping them protected from light, with eyelids of the potential donor closed, and under gauze moisten with saline solution. The maximum time of extracorporeal preservation is 14 days when observing the maintenance care guidelines [12].

The ocular banks that make up the Eye Bank Association of America (EBAA) presented a growth of $1.5 \%$ in total donations and 1.8\% in donated corneas in 2015 compared to 2014 [13].

In Brazil, 14,534 corneas were donated and transplanted in 2016; however, 10,923 people were still on the waiting list of cornea recipients [14].

Paraná reached a number of donations in 2012 sufficient to meet the state demands of recipients and offer corneas to other Brazilian states [15]. Although a waiting list of recipients emerged again after that year, only 18 patients were in the list for corneal transplantation in July 2017, with a maximum surgery waiting time of one week [16].

The evaluation of cornea donation according to patient-related aspects has been the objective of many studies [17-19]. Nevertheless, studies that evaluate the system of cornea donation or its managerial aspects are still scarce. This scarcity is worrisome because it hinders the development of public policies and strategies for managers to measure performance, optimize the functioning of health services, and achieve their goals $[20,21]$.

In this perspective, this study analyzed the cornea donation in the State of Paraná-Brazil in the period from 2011 to 2016.

\section{Methods}

This was an evaluative and cross-sectional, study conducted in the State of Paraná, encompassing four health macro-regions that are the headquarters of the four Organ Procurement Organizations (OPO) of the State.

The data sources were 9,524 medical records of potential donors with death due to brain death and effective cornea donors who died of CRA in the state of Paraná between January of 2011 and December of 2016. 


\section{Nursing \& Healthcare International Journal}

The access to the database was provided by the Transplant Central of the State of Paraná (CET-PR).

Only eligible cornea donors who died at ages between two and eighty years and those who do not present risks of disease transmission through the graft as established by the current legislation described in the Administrative Rule No. 2,600 of October 21 of 2009 and were included in this study [22]. The studied variables were donor age (between 2 and 80 years); gender (female and male); year of donation (2011, 2012, 2013, 2014, 2015, and 2016); notifying health macro-regional (east, north, west, and northwest); type of death (CRA or encephalic death); effective donation (yes or no); non-donation reason (family refusal, validity, positive serology, clinical contraindication, outside the age range for cornea donation, cornea with infiltration, hemolysis - no serology, compromised cornea quality, and time validity for corneal harvest), and reasons for cornea disposal (cornea with infiltration, hemolysis - no serology, perforated cornea, corneal contamination, compromised corneal quality, positive serology, corneal validity/preservation, and other unspecified cause).

Data were analyzed in the Statistical Package for Social Sciences (SPSS) version 20.0. The descriptive statistical analysis calculated absolute and relative frequencies and medians and interquartile ranges; the KolmogorovSmirnov test indicated a non-normal data distribution. Odds ratios were used to assess associations between variables with a confidence interval of $95 \%$. Differences were determined using the Wald test with $\mathrm{p}<0.05$ being considered statistically significant.

The study complied with the ethical aspects established and was approved by the Research Ethics Committee of the Londrina State University (UEL) under opinion no 1395408 .

\section{Results}

A total of 9,524 potential donors were identified between January of 2011 and December of 2016 in Paraná. Out of this total, 7,622 were eligible to donate corneas. The prevalence of corneal donation was $86.9 \%$, of which $44.4 \%$ were discarded (Figure 1 ).

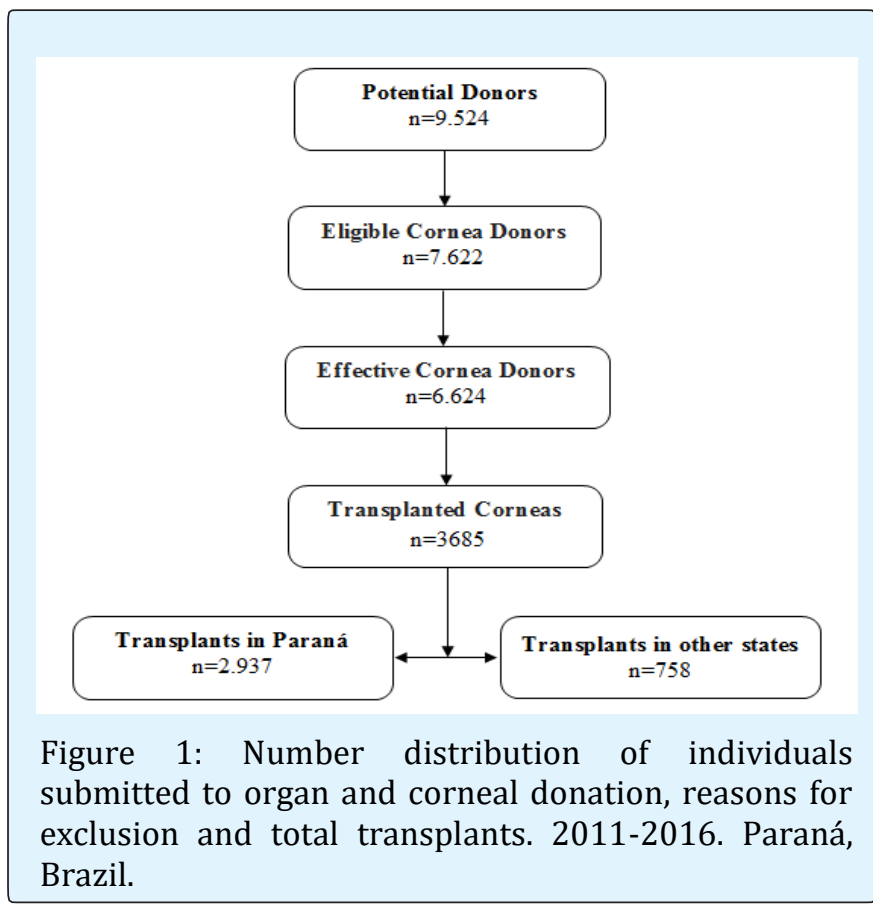

Table 1 shows the variables associated with the process of cornea donation among eligible donors. Men donated 1,655 more corneas than women. Donation from individuals who died of brain death was 705,233 times greater than from CRA death. A significant decrease in cornea donations was observed as the years progressed within the studied period. The Eastern macroregional showed the best performance in donations, with $88.4 \%$ of all cornea donations in Paraná.

\begin{tabular}{|c|c|c|c|c|}
\hline \multirow{3}{*}{ Variables } & \multicolumn{2}{|c|}{ Corneal Donation } & \multirow{3}{*}{$p$-value ${ }^{*}$} & \multirow{3}{*}{$\begin{array}{l}\text { Odds ratio (confidence } \\
\text { intervalo of } 95 \% \text { ) }\end{array}$} \\
\hline & Yes & No & & \\
\hline & n (\%) & n (\%) & & \\
\hline Age & \multicolumn{2}{|c|}{$50(32-60)^{* *}$} & 0,090 & $0,997(0,992-1,001)$ \\
\hline \multicolumn{5}{|c|}{ Gender } \\
\hline Male & $4545(88,9)$ & $568(11,1)$ & & \\
\hline Female & $2079(82,9)$ & $430(17,1)$ & $<0,001$ & $1,655(1,445-1,895)$ \\
\hline \multicolumn{5}{|c|}{ Type of death } \\
\hline Encephalic & \multirow{2}{*}{$5731(99,8)$} & \multirow{2}{*}{$9(0,2)$} & & \\
\hline death & & & & \\
\hline
\end{tabular}




\section{Nursing \& Healthcare International Journal}

\begin{tabular}{|c|c|c|c|c|}
\hline CRA & $893(47,4)$ & $989(52,6)$ & $<0,001$ & $705,233(364,477-1364,567)$ \\
\hline \multicolumn{5}{|c|}{ Year } \\
\hline 2011 & $1102(96,8)$ & $37(3,2)$ & $<0,001$ & $<0,001$ \\
\hline 2012 & $1561(96,4)$ & $58(3,6)$ & $<0,001$ & $0,904(0,594-1,375)$ \\
\hline 2013 & $1116(92,9)$ & $85(7,1)$ & $<0,001$ & $0,428(0,297-0,654)$ \\
\hline 2014 & $764(92,7)$ & $60(7,3)$ & $<0,001$ & $0,255(0,174-0,651)$ \\
\hline 2015 & $857(88,4)$ & $113(11,6)$ & $<0,001$ \\
\hline 2016 & $1224(65,5)$ & $645(34,5)$ & $0,064(0,045-0,090)$ \\
\hline \multicolumn{5}{|c|}{ Macroregional } \\
\hline North & $1193(85,3)$ & $206(14,7)$ & $<0,001$ & $0,761(0,611-0,948)$ \\
\hline Northwest & $789(81,5)$ & $179(18,5)$ & 0,015 & $1,322(1,103-1,584)$ \\
\hline West & $3062(88,4)$ & $400(11,6)$ & 0,003 & $1,281(1,043-1,573)$ \\
\hline East & $1580(88,1)$ & $213(11,9)$ & 0,018 &
\end{tabular}

Table 1: Variables associated with corneal donations (n=7.622). 2011-2016. Paraná, Brazil

*Wald test

**Medians (interquartile ranges)

\section{Discussion}

In the process of cornea donation, from the identification of potential donors to the capture of the ocular globe, removal of the cornea, and subsequent transplantation, several events occur with consequent loss of ocular tissues [23-26]. In the present study, out of the 9,524 potential donors, 7,622 were eligible cornea donors, of which 6,624 effectively donated and out of these, 3,685 had their corneas transplanted into a recipient.

Considering the number of eligible donors and the effective cornea donation, a loss of almost 1,000 ocular tissues (13.09\%) occurred because of family refusal, positive serology, hemolysis (without serology), compromised cornea quality, and restraining time for corneal harvesting. In addition, a high percentage of collected corneas were discarded (44.4\%).

Studies conducted in smaller databases indicated lower percentages of discards according to research conducted in an eye tissue bank in Northeastern Brazil reported 1,209 collected corneas and 341 discarded ones, indicating a loss of $28.2 \%$ [23]. In Rio Grande do Norte, the discharge rate was $21.9 \%$, i. e., out of the 548 captured corneas, 120 were discarded based on stromal infiltrate, positive serology, and restraining time for cornea harvesting [24].

In this study, the losses before and after donation were also more significant when related to positive serology. From a total of $13.09 \%$ losses, $3.54 \%$ was based on positive serology before donation; $19.88 \%$ of the discharged corneas were based on positive serology after the effective donation. From the time of death and donation authorization by the family, there is a six-hour interval for corneal uptake in the PCR. The fact is that serologies are also collected during this time, and the result can be released after these six hours [12], therefore, the discard can also occur after the donation has taken place.

Studies have demonstrated that family refusal is one of the main reasons for non-donation. The fact occurs both in relation to the non-donation of corneas [26] and the non-donation of other organs and tissues $[27,28]$. This refusal can be motivated by the incomprehension of the diagnosis of brain death by family members, religious beliefs, and unpreparedness on the part of the professional who performed the interview [29].

Despite the losses, 2,947 corneas were transplanted in the State of Paraná and 738 were forward for transplantation in other states. This only occurs when there is no recipient in the state of origin since the waiting list for transplantation is unique in each state [22]. Therefore, the excess corneas became available to the National Transplant System. This study demonstrates the success of the donation and transplantation process carried out in the state of Paraná by the current management, benefiting in-state and out-of-state patients.

Considering donors' gender, donations were more effective among men, which corroborates the findings of a survey carried out in five hospitals in Espírito Santo showing $82.8 \%$ of male enrollment [18]. Another study that traced the epidemiological profile of cornea donors 


\section{Nursing \& Healthcare International Journal}

conducted in Goiás identified $81.21 \%$ of donors as men [30].

According to cultural aspects, man is a strong being, who hardly gets sick and almost does not seek health services due to his perception of invulnerability; however, these masculine values lead to risky behaviors [31]. For the most part, men do not seek care for follow-up or prevention of injuries. However, they seek health care in times of urgency and/or emergency, after serious intercurrences [32]. Thus, the number of men who die is higher than the number of women, explaining the fact that most corneal donors are male.

Donation effectiveness was greater in patients deceased by brain death compared to CRA. It is believed that the health team has more time to prepare the family for a possible donation in cases of brain death because it indicates the severity of the patient's clinical frame early in the potential death process, which results in several interactions between the family and health professionals. Moreover, in cases of CRA, the family almost concomitantly receives the news about the death and is questioned about organ donation [33].

In the family approach to donation, the family finds itself in a conflicting moment of emotional frailty triggered by the bereavement process [34]. Thus, the way and the moment in which the family is informed about the death of their loved one is fundamental for the discussion and decision-making about the donation or not of organs and tissues for transplantation [33].

In Paraná, a significant drop in the number of cornea donations was observed over the years within the studied period. Similarly, a study carried out evaluating medical records from an eye bank of the Cologne university hospital in Germany within a period similar to the present study (July 2011 to December 2015) showed a decrease in the number of cornea donations from $11.5 \%$ in 2011 to $3.5 \%$ in 2015 [35].

Society awareness is fundamental in order to increase the number of cornea donations especially regarding the importance of donations to support transplantation, which is the only alternative treatment for patients with chronic-degenerative corneal pathologies. The content of this subject can be disseminated through educational actions in newspapers, magazines, radio, television, and the internet [36,37]. In addition, an improved preparation of professionals who are in charge of approaching families focusing on a humanized communication, clarity of information, and openness to answer questions about the process of donation and transplantation may increase the number of effective donations [38].

It is important to note that, despite the decrease in cornea donations over the years, Paraná remains the second absolute Brazilian state of potential donors and effective donors, becoming the first in potential donors per million population [14].

The Eastern Macroregional showed the best performance in cornea donations in this study. This might be the result of the greater coverage of cornea capturing services in this region compared to others in the state, fundamental for the process with consequent success in the coverage of corneal capture services [39].

Furthermore, the capital of the state of Paraná is located in this macro-region, which may, in some way, facilitate logistical procedures and meet the time constraints for harvesting between death, cornea donation, and ocular globe enucleation.

The limitation of this study is based on the use of secondary data, which presented some biases related to incomplete medical records, system failures, and loss of information. In addition, all CRP cases were not evaluated, only those that effectuated the donation.

The analysis of the system of cornea donation in the State of Paraná-Brazil can contribute to improving strategies and public policies that will improve the quality of care provided and help increasing cornea donation in Paraná. Thus, investing in the training of health professionals involved in the process and sensitizing undergraduate courses toward the insertion of this subject into the curricular guidelines becomes fundamental.

\section{Conclusion}

This study showed that there were $86.9 \%$ of effective donations out of the 7,622 eligible cornea donors; out of this $86.9 \%, 55.6 \%$ were transplanted, and the remaining were discarded as improper for use based on the compromised material. The odds of donation were higher among men than women and among deaths due to brain death in the Eastern Macroregional. In addition, a significant drop in the number of donations was observed over the years within the studied period. 


\section{Nursing \& Healthcare International Journal}

\section{References}

1. Santos NC, Bezerra VL, Melo EC (2014) Characteristics of corneal donations in state of Piauí. Revista Brasileira de Oftalmologia 73(6): 351-357.

2. Gain P, Jullienne R, He Z, Aldossary M, Acquart S, et al. (2016) Global survey of corneal transplantation and eye banking. JAMA Ophthalmol 134(2): 167-173.

3. Gupta NG, Vashist P, Tandon R, Gupta SK, Dwivedi S, et al. (2015) Prevalence of corneal diseases in the rural Indian population: the Corneal Opacity Rural Epidemiological (CORE) study. Br J Ophthalmol 99: 147-152.

4. Brasil (2016) Saúde. Informe-se sobre o tempo de isquemia de cada órgãos.

5. Natarajan S (2014) A close look at cornea. Indian J Ophthalmol 62(4): 381-382.

6. Albert DM, Gamm DM (2017) Cornea. Britannica Academic.

7. Mohan RR, Rodier JT, Sharma A (2013) Corneal gene therapy: Basic science and translational perspective. Ocul Surf 11(3): 150-164.

8. Almeida, HG, Fernandes VB, Lucena ACVP, Kara Junior $N$ (2016) Evaluation of ophthalmologic emergencies in a public reference hospital in Pernambuco. Brazilian Journal of Ophthalmology 75(1): 18-20.

9. Zeschau A, Balestrin IG, Stock RA, Bonamigo EL (2013) Indications of keratoplasty: a retrospective study in a University Hospital. Brazilian Journal of Ophthalmology 72(5): 316-320.

10. Vazirani J, Basu S (2013) Keratoconus: current perspectives. Clin Ophtalmol 7:2019-30.

11. Hashemi H, Beiravand A, Khabazkhoob M, Asgari S, Emamian MH, et al. (2013) Prevalence of Keratoconus in a Population-based Study in Shahroud. Cornea 32:1441-1445.

12. Bonfadini G, Roisman V, Prinz R, Sarlo R, Rocha E, Campos M (2014) Donation and row of corneal transplants in the State of Rio de Janeiro. Brazilian Journal of Ophthalmology 73(4): 237-242.

13. Eye Bank Association of America (2016) EBAA. 2015 Eye Banking Statistical Report.
14. Brazilian Association of Organ Transplants - ABTO (2017) RBT - Brazilian Registry of Transplants. Numerical data on donation of organs and transplants performed by state and institution in the period: janeiro/junho. Ano XXIII no 2.

15. Paraná. State Agency of News (2016) Paraná increases by $40 \%$ the number of transplants.

16. Paraná. Department of Health (2017) Paraná zeros row for cornea transplant.

17. Almeida HG, Souza ACD (2014) Epidemiological profile of patients in the row of cornea transplants in the state of Pernambuco - Brazil. Brazilian Journal of Ophthalmology 73(1):28-32.

18. Rocon PC, Almeida AV, Paro FM (2015) Epidemiological profile of donors of corneas and organ donors from five hospitals in the State of Espírito Santo, Brazil, Brasil. Brazilian Journal of Health Research 17(1): 56-64.

19. Cruz GKP, Junior MAF (2016) Cornea transplantation in Rio Grande do Norte: epidemiological and clinical aspects Online braz j nurs 15 (suppl): 579-582.

20. Costa CKF, Balbinotto Neto G, Sampaio LMB (2014) Efficiency of the Brazilian states and the Federal District in the public kidney transplant system: an analysis using DEA (Data Envelopment Analysis) method and Malmquist index. Cadernos de Saúde Pública 30(8): 1667-1679.

21. Siqueira MM, Araújo CA, Roza BA, Schirmer J (2016) Efficiency indicators to assess the organ donation and transplantation process: systematic review of the literature. Rev Panam Salud Publica 40(2): 90-97.

22. Brasil. Minister's office. Ordinance No. 2,600, of October 21, 2009. Approves the Technical Regulation of the National System of Transplants.

23. Freire ILS, Silva MF, Gomes ATL, Vasconcelos QLDAQ, Araújo RO, et al. (2014) Use of corneas captured and processed for transplantation in a bank of ocular tissues in the Northeast. Rev. Gaúcha Enferm 35(3): 14-20.

24. Freire ILS, Araújo RO, Vasconcelos QLDAQ (2015) Causes of corneal discarded by the eye tissue bank of Rio Grande do Norte. J res fundam care 7(1):18671874. 


\section{Nursing \& Healthcare International Journal}

25. Barreto BS, Santana RJB, Nogueira EC, Fernandez BO, Brito FPG (2016) Factors related to non-donation of organs from potential donors in the state of Sergipe, Brazil, Brasil. Brazilian Journal of Health Research 18(3): 40-48.

26. Diaz FBBS, Ribeiro L, Chaoubah A (2017) Analysis of the Factors that Influence the Cornea Donation Process. Revista de Enfermagem UFPE 11(4): 16921700.

27. Barboza AP, Faraco BR, Zuconi CP (2015) Entrevista Familiar. In: Garcia $C D$, et al. Organ and tissue donation and transplantation $1^{\text {st }}(\mathrm{edn})$, São Paulo: Farma Segment 560.

28. Donoso MTVD, Gonçalves VAMS, Mattos SS (2013) The patient's family versus organ donation: an integrative review. R Enferm Cent O Min 3(1).

29. Rosário EN, Pinho LG, Oselame GB, Neves EB (2013) Family refusal before a potential organ donor. Cad Health Colet. 21(3): 260-266.

30. Silva RE, Morato RM, Veneziano RTS, Rodrigues FW (2016) Epidemiological profile of cornea donors in the State of Goiás. Brazilian Journal of Ophthalmology 75(4): 274-278.

31. Levorato CD, Mello LM, Silva AS, Nunes A (2014) Factors associated with the demand for health services from a gender perspective. Science \& Collective Health 19(4): 1263-1274.

32. Moura EC, Santos W, Neves ACM, Gomes R, Schwarz E (2014) Men's health care under the Family Health Strategy. Science \& Collective Health 19(2): 429-438.
33. Maynard LOD,Lima IMSO, Lima YOR, Costa EA (2015) Conflicts of Consent about the Donation of Post Mortem Organs in Brazil. R Dir sanit 16(3): 122-144.

34. Pessoa JLE, Schirmer J, Roza BA (2013) Assessment of causes of family refusal to donation of organs and tissues. Acta Paulista de Enfermagem 26(4):323-330.

35. Schaub F, Simons HG, Enders P, Bachmann BO, Roters $S$ (2016) et al. Corneal donation: [Corneal donation: Dilemma between growing demand and declining donor rate]. Ophthalmologe 113(12): 1058-1065.

36. Feeley TH, O mally AK, Covert JM (2016) A content analysis of organ donation stories printed in U.S. Newspapers: application of newsworthiness. Health Commun 31(4): 495-503.

37. Freeman B, Potente S, Rock V, Mc Iver J (2015) Social media campaigns that make a difference: what can public health learn from the corporate sector and other social change marketers? Public Health Res Pract 25(2): e2521517.

38. Freire ILS, Mendonça AEO, Freitas MB, Melo GSM, Costa IKF, et al. (2014) Comprehension the nursing team on brain death and organ donation. Enferm. Global 36.

39. Freire ILS, Vasconcelos QLDAQ, Torres GV, Araújo EC, Costa IKF, et al. (2015) Structure, process and result of donation of organs and tissues for transplantation. Brazilian Journal of Nursing 68(5): 837-845. 